\title{
Improving Oral Communicative Competence in English Using Project-Based Learning Activities
}

\author{
Noor Idayu Abu Bakar ${ }^{1}$, Nooreen Noordin ${ }^{2} \&$ Abu Bakar Razali ${ }^{2}$ \\ ${ }^{1}$ Department of General Studies, MARA Skills Institute, Melaka, Malaysia \\ ${ }^{2}$ Faculty of Educational Studies, Universiti Putra Malaysia, Selangor, Malaysia \\ Correspondence: Noor Idayu Abu Bakar, Department of General Studies, MARA Skills Institute, Jasin, P.O Box \\ 141, 77008, Melaka, Malaysia.
}

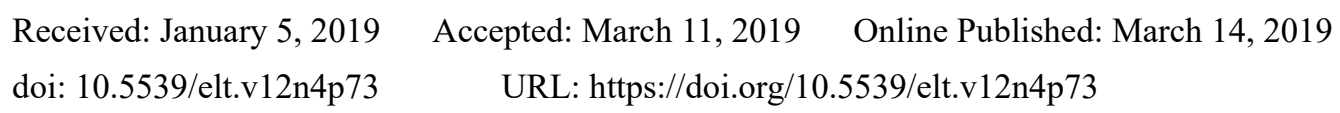

\begin{abstract}
The quasi-experimental study investigated the effectiveness of using project-based learning (PjBL) activities as a teaching strategy in improving the oral communicative competence of Malaysian English language learners. The participants included 44 diploma students enrolled in a Communicative English course at a technical college in the Peninsular Malaysia, who were purposely selected for the study. The intervention comprised a 12-week lessons taught using PjBL teaching strategy and centred on eight $\mathrm{PjBL}$ activities. Data were collected using a speaking test and a listening test, which were administered as pre-tests and post-tests, and a student questionnaire which was administered at the end of the study. Data analysis involved the procedure of MANOVA, as well as descriptive statistics such as mean, standard deviation and percentage. The findings revealed a significant improvement in the learners' overall oral communicative competence and a high perception of PjBL by the learners. It is concluded that $\mathrm{PjBL}$ teaching strategy is effective in improving the oral communicative competence of the English language learners. The study recommends the use of PjBL as a suitable English language teaching strategy for technical students who are generally low proficient English language learners.
\end{abstract}

Keywords: communicative competence, English language learners, listening skill, project-based learning, speaking skill, tertiary education

\section{Introduction}

Communicative competence is the aim of the $21^{\text {st }}$ century language learning (Eaton, 2010). The literature related to English language teaching has reported various strategies employed by English language teachers worldwide to enhance communicative competence. However, these efforts seem to have not alleviated the problem of poor English language competency among learners, particularly in Malaysia. Over the past few years, the poor command of English language among Malaysian students has been widely reported by the local media, stirring up public concerns (The Malay Mail, $11^{\text {th }}$ November 2015; The Sun Daily, $10^{\text {th }}$ December 2015; The Star Online, $25^{\text {th }}$ March 2017). Even worse is at tertiary level, Malaysian students' lack of English language competency is often associated with its impact on the employability of graduates (Mustapha \& Yahaya, 2013).

As immediate providers of workforce, the Malaysian higher education institutions are accountable to prepare job-ready graduates who possess the qualities of a Malaysian graduate as prescribed in the Malaysian Education Blueprint (2013-2025) (Ministry of Education Malaysia, 2015). According to Sada, Abd Hamid, Ahmad and Audu (2015), it has become a recent trend for industries to demand for workers who are job-ready, or in other words, workers who are equipped with hard skills to do a job and soft skills, including communication skills, to immediately assimilate in the working environment. The claim is supported by Sulaiman and Ambotang (2017) who asserted that the employability of graduates could be largely enhanced if the graduates grasp the English communication skills. In all, Malaysian graduates who do not possess the ability to communicate competently in English are likely to face difficulties to secure a job and adapt to the employment world when employed in the future.

The present study focuses on English language learners from the technical field in Malaysia for particular reasons. Abdullah and Abd Majid (2013) mentioned that poor command of English has been identified as the main reason in the issue of unemployability among technical graduates in Malaysia, suggesting that focus be 
given to alleviate this problem among English language learners from the technical field. In addition, low academic requirements stipulated for admission into technical programmes at Malaysian technical and vocational education and training (TVET) institutions, that reflect general differences in students' academic background between universities and technical institutions (Affero \& Hassan, 2013), indicate that the issue of poor English command is likely to be more critical among the students at technical and vocational institutions than those at the university. Besides that, a review of the current literature found that there is still a lack of studies in English language teaching conducted among technical students in Malaysia, which can be referred to or reflected by the local English language teachers and practitioners with regard to English language teaching practices in technical education institutions. The limited information about the teaching practices at the particular education institutions is said to only cause poor perceptions of the TVET field (Kim \& Hassan, 2018). As a result, the country's recent aim to elevate the TVET education will be hampered (Bernama, $21^{\text {st }}$ June 2018). Given the situation, determining the actual effect of PjBL on the TVET learners' improvement in English is crucial. Apart from that, obtaining the opinions from these technical students about their experience in learning English also seems plausible and important to be initiated in order to identify their problems or needs so that adjustments can be made to support their learning. It is likely that the information gathered will give the exposure needed to elevate the TVET field in Malaysia.

Hence, this study attempts to ascertain the effectiveness of using project-based learning activities as a teaching strategy on the oral communicative competence of English language learners from a technical college. The study also gathers the opinions of the English language learners related to the effectiveness of the teaching strategy from their experience during the implementation of the study in a Communicative English course. The data gathered from the participants of the study are anticipated to provide useful insights on the English language learning environment in TVET institutions in general, and in particular the effectiveness of the PjBL teaching strategy to improve the English communicative competence of the learners at the study setting.

\section{Literature Review}

Project-based Learning (PjBL) is a constructivist teaching strategy that involves exploration of knowledge as students work on a project over an extended period of time (Buck Institute for Education, 2018). Kirschner, Sweller and Clark (2006) claimed that minimal guided learning during instruction such as in constructivist learning does not work. However, the benefits of PjBL have been extensively reported in the recent literature. $\mathrm{PjBL}$ offers a lot of learning opportunities for learners to practise using the target language at numerous constructive stages mainly through group discussions and collaboration in completing a project (Kamaruzaman, Baharuddin, Khairul Azhar, \& Nik Azida, 2010; Papanikolaou \& Boubouka, 2010). Scaffolding in PjBL also supports student learning and engagement (Salam, Mailok, Ubaidullah, \& Ahmad, 2016). In addition, authentic activities in $\mathrm{PjBL}$ are fascinating that they make language learning more meaningful and communication more purposeful (Thi, 2011). The strength of PjBL is also often associated with fostering the learning skills of the $21^{\text {st }}$ century such as problem solving, critical thinking, decision making, teamwork and communication (Woro Sumarni, 2015). Student learning engagement is also improved as a result of PjBL. Abdul Khalek and Lee (2012) observed students' class participation and highlighted improved student engagement as the outcome of $\mathrm{PjBL}$. The study found that PjBL could support student engagement in terms of improved responsibility, collaboration, strategic learning and motivation. Besides that, teachers also agree that $\mathrm{PjBL}$ is a beneficial teaching strategy. Mohd Yusof, Musta'amal, Audu and Ismail (2015) who conducted a preliminary study on the implementation of $\mathrm{PjBL}$ at a Malaysian polytechnic found that teachers believed $\mathrm{PjBL}$ was a fascinating teaching strategy owing to its embedded element of project authenticity which could be associated to the real world. In a study by Habók and Nagy (2016), it was revealed that teachers believed PjBL was appropriate for low achievers. It was concluded in the study that $\mathrm{PjBL}$ assessment that considers teamwork and social skills rather than only academic performance is an incentive to the low achievers to participate in $\mathrm{PjBL}$ activities as their efforts will be reflected in their grades too.

Meanwhile, in the context of ESL, the potential of using PjBL as an effective teaching strategy for English language learners has been long discussed by scholars in the literature. In an early discussion of PjBL in English language learning laid by Moss and Van Duzer (1998), it is asserted that PjBL application in English language learning is relevant because it bridges the gap between using English in class and using English in real life situations outside the class. In a recent discussion, Miller (2016) also believes that PjBL is a teaching strategy that offers English language learners the same opportunity as the native speakers to interact in authentic communication situations. He maintains that no other communication situation is as authentic as involving in the actual communication situations with real people in solving a realistic problem like executing a project. In the context of teaching English in a TVET environment, Abd Majid, Abd Rahim, Ab Rahman and Zolkepli (2016) 
suggest that student-centred learning (such as PjBL) be the base for teaching technical students English for it provides an engaging learning environment that promotes internalization of language skills.

Several empirical studies have established the effectiveness of PjBL in English language learning, too. Newprasit and Seepho (2015) conducted a pre-experimental study in Thailand and found that the overall English language skills of the English language learners in their study improved significantly after the implementation of PjBL in the English course. In a case study in India, Shanthi and Rao (2015) investigated the impact of PjBL in improving learners' oral communication skills and found that students developed better speaking and listening skills in English when PjBL was used, owing to the nature of group work in PjBL. In China, Zhang (2015) conducted a study at a speaking and listening college and discovered that the students generally had positive views towards PjBL after attending the PjBL course. Results from the questionnaire showed that PjBL offered ample opportunity for active learning, enhanced students' English reading skills and increased their ability to use online resources. PjBL seemed to match the English teaching and learning need in China because of the current English curriculum requirements that emphasized on the importance of providing students the opportunities to use as much English as they could in real life contexts.

Kalabzov (2015) felt that the lack of teacher control over the weaker students in PjBL might jeopardize their learning. However, $\mathrm{PjBL}$ has been found to be suitable for low proficient English language learners. The findings of the case study conducted by Omar, Taib and Basri (2012) revealed that students with low to medium English proficiency were more familiar with the English language and eventually became more confident to speak in English as a result of the PjBL learning environment in the study setting. It was because the less proficient English language learners received the assistance needed from the more proficient group members so that they could grasp the language more effectively. The study concluded that PjBL encouraged communication to occur even among learners with low level of English proficiency through its extended activities and collaborative nature of PjBL.

Together, there seems to be a strong support for $\mathrm{PjBL}$ as a promising teaching strategy for English language learners including those from the technical field and also those who are generally low proficient in English. Nevertheless, despite the encouraging evidence in the literature, very limited studies appear to measure the actual effectiveness of PjBL by employing an experimental design, which in turn opens the opportunity to conduct another PjBL study by employing an experimental design. Thus, using a quasi-experimental design, the present study sought to determine the effectiveness of using project-based activities as a teaching strategy (PjBL teaching strategy) in improving the oral communicative competence of English language learners from a technical college. It also investigated the perceptions of English language learners regarding the effectiveness of using PjBL teaching strategy in a Communicative English course. The following research questions and hypothesis were explored:

1) Do the English language learners who are taught using PjBL teaching strategy outperform those who are taught using the conventional teaching strategy in their oral communicative competence?

Ho: There is no significant difference in oral communicative competence of the English language learners based on teaching strategies.

2) What are the English language learners' perceptions of PjBL as a teaching strategy in the Communicative English course?

\section{Method}

\subsection{Participants and Context}

The participants in this study were 44 diploma level students from an electrical programme who registered in a Communicative English course at a technical college located in Peninsular Malaysia. They were between 21 and 26 years old, from the Malay race whose first language was Malay and spoke only the first language at home. Demographic information collected prior to the experiment also revealed that most of the students obtained grades from $\mathrm{D}$ and below in the national examination, known as the Malaysian Certificate of Education, which was taken at secondary level prior to their tertiary education. Therefore, the participants of the study could be described as relatively low proficient English language learners. These students were purposely selected based on their availability to participate in the quasi-experimental study. They were divided into the experimental group ( $\mathrm{N}=25)$ and control group $(\mathrm{N}=19)$ based on their intact groups. Specifically, the quasi-experimental study employed a non-equivalent (pre-test and post-test) with control group design. 


\subsection{Instruments}

The instruments used in the study were a speaking test, a listening test, a questionnaire and a 12-week PjBL lesson plans consisting of eight main PjBL activities and scaffolding activities. The self-developed speaking and listening tests followed closely the format and content of the IELTS speaking and listening tests. The speaking test comprised two speaking tasks which were completed individually. The speaking rubric was adapted from Oral Interview Rubric for Communicative Competence by Pillar (2011) and covered criteria such as appropriacy, accuracy, fluency, comprehension, intelligibility, range, kinesics, proxemic and prosodic, as well as task fulfilment. The listening test consisted of 40 items divided into dialogue and monologue listening comprehension questions. The listening scripts, audios and video were adapted from various sources including the internet and ESL books. Meanwhile, the questionnaire was developed by the researchers based on the current literature and was divided into two parts. The first part contained seven items related to the subjects' demographic information while the second part consisted of 20 Likert scale items on the learners' perceptions of the benefits of PjBL on their English language after the intervention. The content-validity of the speaking and listening tests was checked by a panel of experts from the ESL and TVET fields and all the instruments were piloted before they were utilised. Reliability coefficients of .94 obtained for the questionnaire and .97 for the speaking test indicated good values to commence the present study. The listening test also had an acceptable Cronbach's alpha value of .71.

The intervention consisted of a series of PjBL lessons, which were conducted for two hours per week, for twelve consecutive weeks. Similar to the aim of the Communicative English course, the PjBL lessons that included the main project, main PjBL activities and scaffolding activities were aimed at developing the learners' oral English proficiency, in meeting their needs for industrial training and workplace. The lessons were structured based on eight PjBL activities or also known as PjBL phases, based on the PjBL principles put forward by Larmer, Mergendoller and Boss (2015). The eight main PjBL activities were (1) project launching, (2) determining project, final outcome and method of presentation, (3) finding, questioning and evaluating sources of information, (4) presenting the first draft, (5) presenting the second draft, (6) planning and rehearsing for presentation, (7) presenting the final outcome, and (8) reflecting on the project.

\subsection{Research Procedure and Intervention}

Written permission to conduct a study at the particular TVET institution was first gained from the Director of Research and Innovation Section of the technical institution, followed by a meeting with the Deputy Director of Academic Affairs of the institution to explain the purpose and procedures of the study. Written consent was also obtained from every participant prior to the study.

The study was conducted for 16 weeks and divided into three stages; the pre-intervention ( 2 weeks), while-intervention (12 weeks), and post-intervention ( 2 weeks). The speaking and listening tests were conducted as pre-tests during the pre-intervention stage. The while-intervention stage also initiated the commencement of the 12-week PjBL lessons. During the while-intervention stage, the students were taught the Communicative English course using the PjBL teaching strategy, which consisted of eight activities based on the principles proposed by Larmer et al. (2015). The PjBL intervention required the students to work in groups throughout the course to accomplish an interdisciplinary group project. The skills of English language, technical and workplace communication were integrated in the final outcome of the project. During the PjBL lessons, group discussions and group presentations were conducted a lot. In the present study, the projects chosen by the students were based on their field of study and ranged from electrical wiring, installation of electrical devices and repairing and troubleshooting electrical equipment. Besides that, scaffolding activities were also incorporated with the purpose of assisting learners' language learning, content learning and project progress (Buck Institute for Education, 2017). These scaffolding activities comprised a variety of communicative activities that emphasized on speaking and listening skills such as role play, video response and pair discussion, with the contents geared to the specific needs of their technical trade. On the contrary, during the while-intervention stage, the control group was taught the Communicative English course using the conventional teaching strategy prescribed by the class teacher. Typically, the lessons were taught using the PPP method (presentation, practice and production) with a final project assigned at the end of the course. Finally, in the post-intervention stage, the speaking and listening tests were again conducted as post-tests. Besides that, the questionnaire was also administered but only to the experimental group as it sought to explore the learners' opinions about PjBL as a teaching strategy after undergoing the $\mathrm{PjBL}$ intervention.

\subsection{Data Analysis}

Descriptive and inferential statistics were used to analyse the data. To answer Research Question 1, a one-way 
MANOVA procedure was performed and the null hypothesis was tested. MANOVA is appropriate when dependent variables are statistically moderately correlated and share a common conceptual meaning (Pituch \& Stevens, 2009; Leech, Barrett, \& Morgan, 2005). Similarly, in the present study, oral communicative competence was interpreted as the synthesis of English language knowledge and skills of speaking and listening in four sub-competencies (Canale \& Swain, 1980; Canale, 1983); thus, would only be meaningful when measured by combining two dependent variables; speaking and listening skills that share a common conceptual meaning. Next, to answer Research Question 2, data from the PjBL questionnaire were descriptively analysed and the mean, standard deviation and percentage were reported. Together, the results were triangulated to achieve the aim of the study.

\section{Results}

Prior to the main data analysis, intraclass correlation coefficient was computed in SPSS to determine the interrater reliability of speaking scores (Wuensch, 2018; Mandrekar, 2011). The obtained intraclass correlation coefficient values of .89 (pre-test) and .91 (post-test), which were both greater than .70, indicated that there was a high interrater agreement or reliability between raters in scoring the Speaking Test (Koo \& Li, 2016).

\subsection{Pre-tests and Post-tests}

Descriptive data of the speaking and listening tests were first presented in Table 1 below.

Table 1. Results of speaking and listening pre-tests and post-tests in experimental and control groups

\begin{tabular}{llllllllll}
\hline & \multicolumn{4}{c}{ Speaking Test } & \multicolumn{4}{c}{ Listening Test } \\
& N & \multicolumn{2}{l}{ Pre-test } & & \multicolumn{2}{c}{ Post-test } & & Pre-test & \multicolumn{3}{c}{ Post-test } \\
\hline \multirow{3}{*}{ PjBL } & & M & SD & M & SD & M & SD & M & SD \\
Conventional & 25 & 57.74 & 13.68 & 62.62 & 14.09 & 26.20 & 14.72 & 47.80 & 15.23 \\
& 19 & 57.16 & 11.59 & 61.89 & 14.36 & 25.00 & 10.21 & 38.39 & 10.67 \\
\hline
\end{tabular}

From Table 1, we can see that in both tests, the experimental group scored higher on average than the conventional group at post-test, suggesting that the learners who were taught using PjBL outperformed those taught using the conventional teaching strategy in speaking and listening in mean score at the end of the course.

Following the descriptive analysis, a one-way MANOVA procedure was performed to test the hypothesis below:

Ho: There is no significant difference in oral communicative competence of the English language learners based on teaching strategies.

The one-way MANOVA procedure was performed on the speaking and listening post-test data after all the assumptions (including tests of linear relationship, multivariate normality, no multicollinearity and homogeneity of covariance matrices) were checked and fulfilled. Table 2 shows the results of the multivariate test.

Table 2. Results of one-way MANOVA on oral communicative competence based on teaching strategy

\begin{tabular}{lllllll}
\hline & Value & $\mathrm{F}$ & Hypothesis df & Error df & Sig. & Partial Eta Squared \\
\hline Pillai's trace & .143 & $3.431^{\mathrm{a}}$ & 2.000 & 41.000 & .042 & .143 \\
Wilks' lambda* & .857 & $3.431^{\mathrm{a}}$ & 2.000 & 41.000 & .042 & .143 \\
Hotelling's trace & .167 & $3.431^{\mathrm{a}}$ & 2.000 & 41.000 & .042 & .143 \\
Roy's largest root & .167 & $3.431^{\mathrm{a}}$ & 2.000 & 41.000 & .042 & .143 \\
\hline
\end{tabular}

Design: Teaching Strategy.

Computed using alpha $=.05$.

As seen in Table 2, a significant difference was found between the teaching strategies (PjBL and conventional) on the dependent variables (speaking and listening skills), Wilks' Lambda $=.042, F(2,41)=3.431, p<.05$. In other words, there was a significant difference in the overall oral communicative competence when different 
teaching strategies were employed, although partial eta squared value showed a small effect (.143). It was concluded that the null hypothesis was rejected.

\subsection{Questionnaire}

The PjBL questionnaire comprised 20 items with five-point Likert scale which were divided into four categories: Improvement of language skills, development of soft skills, motivation and attitudes, and learning opportunities during project-based activities. The results of the PjBL questionnaire were presented in the following tables according to categories.

\subsubsection{Improvement of Language Skills}

As shown in Table 3, the students agreed $(\mathrm{M}=3.96 ; \mathrm{SD}=0.45)$ that they were a better English speaker than they were before. They also agreed $(\mathrm{M}=4.04 ; \mathrm{SD}=0.61)$ that they understood English conversations that they heard more than before, that they were able to express ideas more freely than before $(\mathrm{M}=3.80 ; \mathrm{SD}=0.58)$, and that their course content knowledge had improved $(\mathrm{M}=4.04 ; \mathrm{SD}=0.68)$. Interestingly, the students showed the strongest agreement $(\mathrm{M}=4.24 ; \mathrm{SD}=0.52)$ with Item $\mathrm{A}$; that they knew more English words than they did before.

Table 3. Improvement of language skills

\begin{tabular}{llll}
\hline No. & Statement & Mean & SD \\
\hline 1. & I am a better English language speaker than I was before. & 3.96 & 0.45 \\
2. & I understand English conversations that I hear now more than I did before. & 4.04 & 0.61 \\
3. & I am able to express my ideas more freely now than I was before. & 3.80 & 0.58 \\
4. & My knowledge of the course content has improved. & 4.04 & 0.68 \\
5. & I know more English words now than I did before. & 4.24 & 0.52 \\
& Overall & 4.02 & 0.57 \\
\hline
\end{tabular}

\subsubsection{Development of Soft Skills}

It is apparent from Table 4 that the overall mean value for perceived development of soft skills is reasonably high ( $\mathrm{M}=4.18 ; \mathrm{SD}=0.63)$. The highest mean value is for Item $\mathrm{B} 6$; the students felt that their collaborative skills had improved as a result of the implementation of the PjBL teaching strategy $(\mathrm{M}=4.44 ; \mathrm{SD}=0.53)$. It is followed by Item $\mathrm{B} 10$ which stated that they were able to work in groups better $(\mathrm{M}=4.28 ; \mathrm{SD}=0.68)$. The students agreed $(\mathrm{M}=4.08$; SD: 0.49), that their research skills had improved that they became more creative thinkers $(\mathrm{M}=4.08$; $\mathrm{SD}=0.70)$ and were able to manage work as planned $(\mathrm{M}=4.04 ; \mathrm{SD}=0.73)$.

Table 4. Development of soft skills

\begin{tabular}{llll}
\hline No. & Statement & Mean & SD \\
\hline 6. & The activities improve my collaborative skills. & 4.44 & 0.53 \\
7. & The activities improve my research skills. & 4.08 & 0.49 \\
8. & I think more creatively than before. & 4.08 & 0.70 \\
9. & I am able to manage my work according to my plan. & 4.04 & 0.73 \\
10. & I work better in groups now than I did before. & 4.28 & 0.68 \\
& Overall & 4.18 & 0.63 \\
\hline
\end{tabular}

\subsubsection{Motivation and Attitudes}

It can be seen from Table 5 that the highest mean value was devoted to Item $\mathrm{C} 11(\mathrm{M}=4.4 ; \mathrm{SD}=0.71)$ which stated that students enjoyed the activities during the lessons. This is followed by Item $\mathrm{C} 12$, that they appreciated feedback given to them about their project $(\mathrm{M}=4.20 ; \mathrm{SD}=0.58)$. Meanwhile, the students agreed $(\mathrm{M}=3.84$; $\mathrm{SD}=0.75$ ) that they always felt excited about their project and that they communicated confidently during the lessons $(\mathrm{M}=3.60 ; \mathrm{SD}=0.76)$. However, the students were impartial $(\mathrm{M}=3.44 ; \mathrm{SD}=0.71)$ when deciding whether they no longer felt anxious to communicate in English throughout the study. 
Table 5. Motivation and attitudes towards PjBL lessons

\begin{tabular}{llll}
\hline No. & Statement & Mean & SD \\
\hline 11. & I enjoy the activities during the lessons. & 4.40 & 0.71 \\
12. & I am always excited about the project I am doing. & 3.84 & 0.75 \\
13. & I appreciate feedback received about my project. & 4.20 & 0.58 \\
14. & I communicate in English confidently during the lessons. & 3.60 & 0.76 \\
15. & I no longer feel anxious to communicate in English. & 3.44 & 0.71 \\
& Overall & 3.90 & 0.70 \\
\hline
\end{tabular}

\subsubsection{Learning Opportunities in PjBL}

The students on a whole agreed that PjBL provided many learning opportunities through its activities $(\mathrm{M}=3.96$; $\mathrm{SD}=0.76)$. Item $\mathrm{D} 17$ which was related to opportunities to correct mistakes had the highest mean value $(\mathrm{M}=4.12$; $\mathrm{SD}=0.73$ ) in the questionnaire. Meanwhile, the students agreed that they had many opportunities to speak in English $(\mathrm{M}=3.96 ; \mathrm{SD}=0.79)$, to coach their friends $(\mathrm{M}=3.68 ; \mathrm{SD}=0.85)$, to involve in real life communication situations $(\mathrm{M}=4.00 ; \mathrm{SD}=0.58)$ and to determine their own learning $(\mathrm{M}=4.04 ; \mathrm{SD}=0.84)$.

Table 6. Learning opportunities offered in PjBL

\begin{tabular}{llll}
\hline No. & Statement & Mean & SD \\
\hline 16. & I have many opportunities to speak in English. & 3.96 & 0.79 \\
17. & I have many opportunities to correct my mistake. & 4.12 & 0.73 \\
18. & I have many opportunities to coach my friends. & 3.68 & 0.85 \\
19. & I have many opportunities to involve in real life communication situations. & 4.00 & 0.58 \\
20. & I have the freedom to determine how I learn. & 4.04 & 0.84 \\
& Overall & 3.96 & 0.76 \\
\hline
\end{tabular}

\section{Discussion}

The study investigated the effectiveness of using project-based learning ( $\mathrm{PjBL}$ ) activities as a teaching strategy in improving the oral communicative competence of Malaysian English language learners. Data were gathered from speaking and listening pre-tests and post-tests, and a questionnaire. In this section, the discussion of the results is presented according to the research questions.

\subsection{Effectiveness of PjBL Teaching Strategy in Improving Oral Communicative Competence}

Oral communicative competence in the present study refers to the synthesis of English language knowledge and skills of speaking and listening in four sub-competencies of communicative competence proposed by Canale and Swain (1980) and Canale (1983). In other words, the speaking and listening skills of the English language learners define the concept of oral communicative competence here. In PjBL, the speaking and listening skills are taught in integration through its main activities such as group discussions and group presentations, as well as through its scaffolding activities. In discussing the effects of PjBL on oral communicative competence, it is therefore, practical to integrate the effects on both speaking and listening skills. The current study found that the English language learners in the PjBL group and the conventional group performed differently when different teaching strategies were employed after twelve weeks (Wilks' Lambda $=.042, F(2,41)=3.431, p<.05$ ). A comparison of the mean scores showed that the learners who were taught using PjBL teaching strategy outperformed those who were taught using the conventional teaching strategy. Overall, these results reflect those of Newprasit and Seepho (2015) and Shanthi and Rao (2015) who found the effectiveness of PjBL in improving the English language skills including speaking and listening. The results of the study also provide evidence to corroborate the idea of Abd Majid et al. (2016) who believe that student-centred learning approach is a suitable approach to teach English at TVET institutions. 
The possible reasons for these results can be strongly associated with the communication opportunities in PjBL and authentic contexts in PjBL activities. PjBL is a group-based pedagogy that requires learners to collaborate in groups for an extensive learning time. During group discussions, not only do learners have ample opportunity for interaction and communication with their group members, but interaction in groups is also unavoidable since they share the same goal in the project. Consistent communication with group members reduces the learners' anxiety to speak as they eventually become comfortable communicating with people within the group. Communication opportunities are also provided during group presentations (Habók \& Nagy, 2016; Shanthi \& Rao, 2015). Through presentations, the learners are once again exposed to speaking the English language in a formal situation, as well as to listening to the spoken language, especially during the Q \& A session. In PjBL, learning happens outside the classroom too especially during the information researching phase. Communication may also occur as they refer to various sources to collect information in completing their project, such as from people outside the classroom.

Miller (2016) asserts that PjBL gives learners the opportunity to work and use the academic language for authentic purposes. The use of authentic contexts in PjBL makes the language learnt by the learners more meaningful as the language is relevant to its use in the real world; thus, fostering the internalization of language skills including speaking and listening. Projects that are authentic to the students' lives also keep them engaged in the language. In much the same way, the learners in the present study were exposed to authentic contexts as their project was designed to be realistic and applicable to the real world based on their field of study. Thus, the language acquired in completing the project is likely to be meaningful that it will be useful to the learners in the real world after their studies, especially at workplace.

The results of the study also suggest that the technical students in the present study who are generally low proficient in English could improve their oral communicative competence when taught using PjBL. Put differently, the study gives the evidence to alleviate the concern expressed by Kalabzov (2015) that PjBL may threaten the learning of the learners who are weak in English due to lack of control over them. The encouraging results are in agreement with the findings of Omar et al. (2012) who found positive effects of PjBL on the medium and low proficient English language learners in their study. A possible explanation for this might be that scaffolding is extensively offered in PjBL (Salam et al., 2016). In accordance with the concept of Zone of Proximal Development (ZPD) by Vygotsky, in PjBL, scaffolding is offered by group members within a group and also by the teacher during PjBL lessons (Habók \& Nagy, 2016; Miller, 2016). Within their groups, the weaker students are assisted by the stronger ones in the project. Meanwhile, scaffolding is offered by the teacher in a more structured way through scaffolding activities which are intended to scaffold content learning, language learning and project progress (Buck Institute for Education, 2017).

\subsection{English Language Learners' Perceptions of the Effectiveness of PjBL Teaching Strategy}

Consistent with the literature, this research found that the English language learners had high perceptions of the effectiveness of the PjBL teaching strategy in the Communicative English course (Woro Sumarni, 2015; Zhang, 2015). The learners believed that the PjBL activities benefited them in developing their English language skills $(\mathrm{M}=4.02, \mathrm{SD}=.57)$, cultivating soft skills $(\mathrm{M}=4.18 . \mathrm{SD}=.63)$, increasing motivation and attitudes towards learning $(\mathrm{M}=3.90, \mathrm{SD}=.70)$, and providing learning opportunities during the lessons $(\mathrm{M}=3.96, \mathrm{SD}=.76)$.

In terms of development of language skills, the learners strongly felt that they learned more new words at the end of the course. This section of the results reasonably matched the result by Poonpon (2011) who revealed that students' vocabulary increased as they encountered new words while researching for information for their project. Besides that, the learners also felt that they understood conversations they heard better. The listening and speaking activities integrated during the lessons as scaffolding activities to support the learners' acquisition of language skills might have helped the learners improve their listening comprehension skill. In PjBL, English language learners (non-native speakers of English) may need to be supported to reduce the linguistic barriers within the context of the project (Buck Institute for Education, 2017). This is especially applicable when teaching low proficient English learners such as those learners involved in this present study.

It is interesting to note that the learners showed reasonably strong agreement with the overall benefits of PjBL in developing their soft skills especially the collaborative and group skills. As a group-based pedagogy, working in groups throughout the PjBL activities is mandatory (Moss \& Van Duzer, 1998). To function as a group, interaction and collaboration between group members are unavoidable. Therefore, it is not surprising that the learners strongly agreed that the PjBL activities managed to develop their collaborative and group work skills. Comparison of the finding with those of other studies confirms that PjBL encourages collaboration and group work (Papanikolaou \& Boubouka, 2010; Masrom \& Md. Yusof, 2013). In addition, working in groups which was 
found to be the most serious problem in PjBL implementation in the study by Zhang (2015) for it caused imbalance of workload among group members, does not seem to be the case here.

The learners were asked to rate their level of agreement with the effects of PjBL on their motivation and attitudes towards learning the Communicative English course. The results indicate a strong agreement that the learners enjoyed the PjBL activities and appreciated the feedback they received during the lessons. This finding is consistent with that of Omar et al. (2012) who found that the students showed much interest in the learning process when they were given the autonomy to organise a project. They were also eager to participate and showed positive attitudes towards the given tasks. A similar finding was also reported by Zhang (2015) who found that students' motivation was enhanced as a result of the PjBL implementation. Despite the enjoyment in the activities, it seems from the results that the learners still had some reservations about the effectiveness of $\mathrm{PjBL}$ in eliminating their anxiety to communicate in English. They also showed a slightly lower agreement that they communicated in English confidently during the course. This outcome is contrary to that of Liyana et al. (2015) who reported that PjBL activities helped to develop students' confidence to communicate in English. The reason for this contradictory result is not clear but might be caused by the difference in the academic background between the participants involved in the present study and those in the study by Liyana et al. (2015), which might have influenced the learners' self-belief and confidence level.

As mentioned in the literature review, PjBL offers a lot of learning opportunities through its constructive stages during project completion (Jusoff, Abdul Rahman, Mat Daud \& Abd Ghani, 2010); Papanikolaou \& Boubouka, 2010). In accordance with the previous studies, this present study revealed that the learners generally agreed that PjBL environment offered a lot of opportunities to correct mistakes, determine own learning, involve in real life communication situations, speak English, and coach others. To explain the results, it is interesting to note again that the opportunity of learning in $\mathrm{PjBL}$ is comparable to the space between the lowest and the highest points in the Zone of Proximal Development (ZPD) proposed by Vygotsky (1978). The researchers were aware that learning opportunity was crucial since the learners who were low achievers, had limited learning capability and might also learn differently. In much the same way, Omar et al. (2012) believed that learning opportunity in PjBL was much needed by low achievers who might need some extra time and assistance, and more practices to progress along with others. Therefore, during the learning process in the present study, the learners were given the flexibility to regulate their own learning in terms of deciding the final outcome, method of presentation, and even the pace of their own learning. During the extended learning process in PjBL too, the learners had a lot of opportunities to discuss with other group members in order to correct their mistakes and improve their project.

\section{Conclusion}

This study set out to find a strategy to teach English that could alleviate the problem of low command of English among the Malaysian graduates. It was aimed at ascertaining the effectiveness of using project-based learning activities as a teaching strategy ( $\mathrm{PjBL}$ teaching strategy) in improving the English language oral communicative competence of learners in an English language course, known as Communicative English, at a technical college in Malaysian. It also gathered the perceptions of the English language learners on the effectiveness of using PjBL teaching strategy in the course. To achieve the aim, the intervention of the study, through 12-week PjBL lessons, was structured to cater to the English language needs of these technical English language learners. The main project was directed towards integrating the learners' skills of English language (learning goals), technical (knowledge and understanding) and workplace communication (success skills) as core elements in designing a project (Larmer et al., 2015), which may not often be highlighted as the primacy in other previous studies of $\mathrm{PjBL}$ in the field of English language.

Overall, the results of the study support the effectiveness of using PjBL as a teaching strategy in English language teaching and learning. The empirical evidence from the present quasi-experimental study shows that $\mathrm{PjBL}$ is not only perceived to be suitable and enjoyable by the English language learners, but is also found to be effective for these learners who are low proficient in English. Furthermore, in a control condition over the extraneous variables, the results of this quasi-experimental study are believed to be least disputable; offering a much stronger support to reinforce similar findings from the observational study by Omar et al. (2012) and the survey conducted by Habók and Nagy (2016). Taken together, this builds up a new understanding that with a careful planning and the right implementation, a minimally guided instructional approach can yield fruitful results and be as effective as a guided instructional approach, regardless of the learners' English language background. From these uplifting results too, English language teachers and educators, particularly those who are attached to technical institutions, are enlightened on the advantages of $\mathrm{PjBL}$ and the possibility of employing $\mathrm{PjBL}$ teaching strategy as an option to teach English in an effective and fun way, which is likely to be favoured by the learners from the technical field who are generally low proficient in English. 
To conclude, it is believed that the strengths of PjBL have enhanced the learners' oral communicative competence, preparing them with the desired quality of Malaysian graduates in a long run, which will ultimately result in improved employability of these graduates. Nevertheless, owing to the small number of participants involved and the unavoidable use of intact groups in this study, caution must be applied when interpreting the results as they only apply to the English language learners who were involved in the study at the study setting. Hence, considerably more empirical work needs to be done in the future in order to corroborate the effectiveness of $\mathrm{PjBL}$ in improving the English language competency of Malaysian language learners, practically, by employing a randomly selected and much larger sample size to enable generalizability of the research findings.

\section{Acknowledgements}

The present study was supported by Majlis Amanah Rakyat (MARA) and the Putra Grant of the Research Management Unit, Universiti Putra Malaysia.

\section{References}

Abd Majid, M. S. Z., Abd Rahim, A. A., Ab Rahman, R., \& Zolkepli, Z. A. (2016). A conceptual framework for teaching English in TVET environment. In 6th National Conference in Education Technical and Vocational in Education and Training (pp. 144-150).

Abdul Khalek, A., \& Lee, A. (2012). Application of Project-Based Learning in Students ' Engagement in Malaysian Studies and English Language. Journal of Interdisiplinary Research in Education, 2(1), 37-46.

Abdullah, S., \& Abd Majid, F. (2013). English Language Teaching Challenges in Malaysia: Polytechnic Lecturers' Experience. World Applied Sciences Journal, 28(4), 540-547.

Affero, I., \& Hassan, R. (2013). Issues and challenges of technical and vocational education \& training in Malaysia for knowledge worker driven. In National Conference on Engineering Technology 2014 (pp. 1-11).

Bernama. (2018, June 21). TVET empowerment committee formed. Bernama.Com. Retrieved from http://www.bernama.com/en/news.php?id=1473646

Buck Institute for Education. (2017). English learner scaffolds for PBL. Retrieved July 14, 2017, from www.bie.org

Canale, M., \& Swain, M. (1980). Theoretical Bases of Communicative Approaches to Second Language Teaching and Testing. Applied Linguistics, 1, 1-47. https://doi.org/10.1093/applin/I.1.1

Cheah, B. (2015, November 10). Poor English among students a grave concern. The Sun Daily. Retrieved from https://www.thesundaily.my

Eaton, S. E. (2010). Global trends in language learning in the twenty-first century. Calgary: Onate Press.

Habók, A., \& Nagy, J. (2016). In-Service Teachers' Perceptions of Project-Based Learning. SpringerPlus, 5(1), 1-14. https://doi.org/10.1186/s40064-016-1725-4

Jusoff, K., Abdul Rahman, B., Mat Daud, K. A., \& Abd Ghani, N. A. (2010). Motivating Students Using Project Based Learning ( PjBL ) via e-SOLMS Technology. World Applied Sciences Journal, 8(9), 1086-1092.

Kalabzov, M. (2015). The application of project based learning in the English classrooms. University of West Bohemia.

Kim, W. L., \& Hassan, A. (2018). Instructional Technology Competencies Perceived by Technical and Vocational Education and Training (TVET) Students in Malaysia. International Journal of Academic Research in Business and Social Sciences, 8(5), 343-366.

Kirschner, P. A., Sweller, J., \& Clark, R. E. (2006). Why Minimal Guidance During Instruction Does Not Work: An Analysis of the Failure of Constructivist, Discovery, Problem-Based, Experiential, and Inquiry-Based Teaching. Educational Psychologist, 41(2), 75-86. https://doi.org/10.1207/s15326985ep4102_1

Koo, T. K., \& Li, M. Y. (2016). A guideline of selecting and reporting intraclass correlation coefficients for reliability research. Journal of Chiropractic Medicine, 15(2), 155-163. https://doi.org/10.1016/j.jcm.2016. 02.012

Larmer, J., Mergendoller, J., \& Boss, S. (2015). Gold Standard PBL: Essential project design elements. Retrieved from https://www.pblworks.org/blog/gold-standard-pbl-essential-project-design-elements

Leech, N. L., Barrett, K. C., \& Morgan, G. A. (2005). SPSS for intermediate statistics (2nd ed.). New Jersey and London: Lawrence Erlbaum Associates. 
Liyana, A. A., Siti Bahirah, S., Bazilah Raihan, M. S., Khairul Hisyam, B., Yohan, K., \& Siti Fariha, M. (2015). Implementing project-based learning called as "Best of Both Worlds Project ( BBWP )" in English syllabus. Researchers World - Journal of Arts, Science \& Commerce, 6(4), 43-47.

Mandrekar, J. N. (2011). Measures of interrater agreement. Journal of Thoracic Oncology, 6(1), 6-7. https://doi.org/10.1097/JTO.0b013e318200f983

Masrom, U., \& Md. Yusof, D. S. (2013). English Games as a Constructivist Approach in Project Based Learning. International Journal of Social Science and Humanities Research, 1(1), 21-25.

Miller, B. A. (2016). The potential of project based learning and English language learners. Curriculum in Context.

Ministry of Education Malaysia. (2015). Malaysia Education Blueprint 2013-2025 (Higher Education). Kementerian Pendidikan Malaysia. Retrieved from http://medcontent.metapress.com

Mohd Yusof, M. N., Musta'amal, A. H., Audu, R., \& Ismail, N. S. (2015). Implementation of project-based learning (PjBL) at a Malaysian polytechnic - A preliminary study. In Proceedings of INTCESS15-2nd International Conference on Education and Social Sciences (pp. 548-554).

Moss, D., \& Van Duzer, C. (1998). Project-based learning for adult English language learners. ERIC Digest, 1-7. Retrieved from http://www.cal.org

Mustafa, S. M., \& Yahaya, R. A. (2013). Communicative Language Teaching ( CLT ) in Malaysian Context: Its Implementation in Selected Community Colleges. Procedia - Social and Behavioral Sciences, 90(InCULT 2012), 788-794. http://doi.org/10.1016/j.sbspro.2013.07.153

Newprasit, N., \& Seepho, S. (2015). The Effects of a Project-Based Learning Approach on the Improvement of English Language Skills. Journal of Applied Language Studies and Communication, 1(June), 16-51.

Omar, A., Taib, N. F., \& Basri, I. S. (2012). Project-Based Learning: English Carnival in Universiti Kuala Lumpur-Malaysia France Institute. The English Teacher, XLI(August), 27-41.

Papanikolaou, K., \& Boubouka, M. (2010). Promoting Collaboration in a Project-Based E-Learning Context. Journal of Research on Technology in Education, 43(2), 135-155. https://doi.org/10.1080/15391523.2010. 10782566

Pillar, G. (2011). A Framework for Testing Communicative Competence. The Round Table: Partium Journal of English Studies, 2(Fall), 24-37.

Pituch, K. A., \& Stevens, J. P. (2009). Applied multivariate statistics for the social sciences (6th ed., Vol. 21). New York and London: Routledge.

Poonpon, K. (2011). Enhancing English Skills Through Project-Based Learning. The English Teacher, XL, 1-10.

Sada, A. M., Abdul Hamid, M. Z., Ahmad, A., \& Audu, R. (2015). Effects of Problem-Based Learning in Teaching and Learning of Technical and Vocational Education and Training. International Journal of Scientific and Research Publications, 5(5), 5-7.

Salam, F., Mailok, R., Ubaidullah, N., \& Ahmad, U. (2016). The Effect of Project-Based Learning Against Students' Engagement. International Journal of Development Research, 6(2), 6891-6895.

Shanthi, W. G., \& Rao, A. R. (2015). Project Based Learning: An Effective Tool for Developing Aural and Oral Skills of Engineering Students - A Study. In International Conference on Humanities, Literature and Management (pp. 9-11). h

Sulaiman, G., \& Ambotang, A. S. (2017). The Role of Basic Vocational Education Towards Students Employability. International Journal of Vocational Education and Training Research, 3(1), 1-6. https://doi.org/10.11648/j.ijvetr.20170301.11

Syed Jaymal Zahiid. (2015, November 11). Poor English eroding Malaysian graduates' self-belief. The Malay Mail. Retrieved from https://www.malaymail.com

Tan, C. (2017, March 25). Poor English skills a major complaint in every industry. The Star Online. Retrieved from http://www.thestar.com.my

Thi, N. V. L. (2011). Project-based Learning in Teaching English as a Foreign Language. VNU Journal of Science, Foreign Languages, 27, 140-146.

Woro Sumarni. (2015). The Strengths and Weaknesses of the Implementation of Project Based Learning: A 
Review. International Journal of Science and Research, 4(3), 478-484.

Wuensch, K. L. (2018). Inter-rater agreement. East Carolina University. Retrieved from https://www.medcalc.org/manual/kappa.php

Zhang, Y. (2015). Project-based Learning in Chinese College English Listening and Speaking Course : From Theory to Practice. Canadian Social Science, 11(9), 40-44.

\section{Copyrights}

Copyright for this article is retained by the author(s), with first publication rights granted to the journal.

This is an open-access article distributed under the terms and conditions of the Creative Commons Attribution license (http://creativecommons.org/licenses/by/4.0/). 